\title{
FORCED LABOR IN NAZI GERMANY: ONLINE ARCHIVE OF INTERVIEWS AND RELATED EDUCATIONAL ONLINE PLATFORM
}

\author{
Doris Tausendfreund \\ Freie Universität Berlin, Berlin, German \\ Natalya P. Timofeeva \\ Voronezh Institute of High Technologies, Voronezh, Russian Federation \\ Tatyana V. Evdokimova \\ Volgograd State Socio-Pedagogical University, Volgograd, Russian Federation
}

\begin{abstract}
Introduction. The article deals with the problem of forced labor in Nazi Germany during the Second World War. Despite the existence of profound scientific publications devoted to this problem in Russia and abroad, it still needs to be developed. The article emphasizes the urgency of its research in historical, anthropological and humanities perspective, because personal experience of those who survived after forced labor in Nazi Germany, must be stored in collective memory and comprehended by subsequent generations. Methods and materials. Digital Humanities based on the method of oral history allows to solve this problem. The article presents two options of practical implementation of the issue: the online archive of the interview Forced Labor in 1939-1945. Memories and history and related online platform Learning based on interviews. Forced labor in 1939-1945. The archive includes about 600 narrative biographical interviews with victims of Nazi forced labor in 26 countries. The site accompanying the archive is now available in English, German, Russian and Czech. The second project is based on six specially selected interviews from the archive. Broad source base and nationally-oriented concept of forced labor in Nazi Germany, presented on the platform, create the historical context necessary for using this resource primarily in the secondary educational system of the Russian Federation. Analysis and results. The article shows the possibility of using archive-interviews in science and education, and emphasizes that traditional $\stackrel{\sim}{\rightarrow}$ and new methods of historical research can complement each other. The article emphasizes that biographical \% films created on the basis of interviews can make the memory of forced labor in Nazi Germany, first of all, of "eastern workers" and Soviet prisoners of war more visible in Russian cultural memory. Contribution of authors to writing an article. Characteristics of peculiarity of oral historical sources, online collections of interviews, compensation payments are given by D. Thousendfreund. Analytics of the project "Forced Labor 1939-1945. Memoirs and History "and online platform" Learning based on interviews. Forced labor 1939-1945", as well as conclusions are prepared by N.P. Timofeev. Introduction, problem historiography and general editing of the article belong to T.V. Evdokimova.
\end{abstract} humanities, online archive, online platform.

Citation. Tausendfreund D., Timofeeva N.P., Evdokimova T.V. Forced Labor in Nazi Germany: Online Archive of Interviews and Related Educational Online Platform. Vestnik Volgogradskogo gosudarstvennogo universiteta.

Seriya 4, Istoriya. Regionovedenie. Mezhdunarodnye otnosheniya [Science Journal of Volgograd State University. History. Area Studies. International Relations], 2019, vol. 24, no. 1, pp. 183-195. (in Russian). DOI: https://doi.org/ 10.15688/jvolsu4.2019.1.16 


\title{
ПРИНУДИТЕЛЬНЫЙ ТРУД В НАЦИСТСКОЙ ГЕРМАНИИ: ОНЛАЙН-АРХИВ ИНТЕРВЬЮ И СВЯЗАННАЯ С НИМ УЧЕБНАЯ ОНЛАЙН-ПЛАТФОРМА
}

\author{
Дорис Таузендфройнд \\ Свободный университет Берлина, г. Берлин, Германия \\ Наталья Петровна Тимофеева \\ Воронежский институт высоких технологий, г. Воронеж, Российская Федерация \\ Татьяна Васильевна Евдокимова \\ Волгоградский государственный социально-педагогический университет, \\ г. Волгоград, Российская Федерация
}

\begin{abstract}
Аннотация. Введение. В статье рассматривается проблема принудительного труда в нацистской Германии в годы Второй мировой войны. Несмотря на посвященные этой проблеме серьезные научные публикации за рубежом и в России, она все еще нуждается в разработке. Подчеркивается насущность ее исследования в историко-антропологической и гуманитарной перспективе, ибо личный опыт тех, кто пережил испытание принудительным трудом в нацистской Германии, должен быть сохранен в коллективной памяти и осмыслен последующими поколениями. Методы и материалы. Цифровая гуманитарная наука позволяет решить данную проблему на основе метода устной истории. В статье представлены два варианта практического воплощения вопроса: онлайн-архив интервью «Принудительный труд 1939-1945. Воспоминания и история» и связанная с ним онлайн-платформа «Обучение на основе интервью. Принудительный труд 1939-1945». Архив включает около 600 нарративно-биографических интервью, состоявшихся с жертвами нацистского принудительного труда в 26 странах мира. Сопровождающий архив сайт действует ныне на английском, немецком, русском и чешском языках. В основе второго проекта лежат шесть специально отобранных интервью из архива. Широкая источниковая база и представленная на платформе национально ориентированная концепция проблемы принудительного труда в нацистской Германии создают исторический контекст, необходимый для применения данного ресурса преимущественно в системе среднего образования Российской Федерации. Анализ и результаты. В статье показана возможность использования архива-интервью в науке и образовании, подчеркивается, что традиционные и новые методы исторического исследования могут дополнять друг друга. Делается акцент на том, что созданные на основе интервью биографические фильмы могут сделать память о принудительном труде в нацистской Германии, прежде всего о «восточных рабочих» и советских военнопленных, более зримой в российской культуре памяти. Вклад авторов в написание ста$m b u$. Характеристика специфики устных исторических источников, онлайн-коллекции интервью, компенсационных выплат дана Д. Таузендфройнд. Аналитика проекта «Принудительный труд 1939-1945. Воспоминание и история» и онлайн-платформы «Обучение на основе интервью. Принудительный труд 1939-1945», а также выводы подготовлены Н.П. Тимофеевой. Введение, историография проблемы и общее редактирование работы принадлежат Т.В. Евдокимовой.

Ключевые слова: принудительный труд, нацистская Германия, Вторая мировая война, устная история, нарративно-биографическое интервью, цифровая гуманитарная наука, онлайн-архив, онлайн-платформа.

Цитирование. Таузендфройнд Д., Тимофеева Н. П., Евдокимова Т. В. Принудительный труд в нацистской Германии: онлайн-архив интервью и связанная с ним учебная онлайн-платформа // Вестник Волгоградского государственного университета. Серия 4, История. Регионоведение. Международные отношения. 2019. - T. 24, № 1. - C. 183-195. - DOI: https://doi.org/10.15688/jvolsu4.2019.1.16
\end{abstract}

Введение. Проблема принудительного труда в нацистской Германии до сих пор не получила должного отражения в науке, не- смотря на ее значение для исследования сложного комплекса вопросов Второй мировой войны, к исходу которой в Третьем рейхе вынуж- 
дено трудились около 20 миллионов человек из всех частей Европы. Более 13 миллионов работали при этом в самом рейхе. Среди них свыше 8 миллионов были гражданские рабочие и работницы, преимущественно из Восточной Европы, и почти 5 миллионов военнопленные. Сюда же относятся около 1 миллиона человек, преследовавшихся в соответствии с нацистской идеологией по расовому признаку, прежде всего, евреи и цыгане, а также около 700 тыс. узников концлагерей, в число которых входили также политические заключенные. Следует отметить, что до сих пор неизвестно число лиц, привлекавшихся вермахтом к принудительным работам на оккупированной нацистской Германией территории европейских стран и Советского Союза [23].

$\mathrm{B}$ соответствии с нацистской иерархией иностранные работники принудительного труда были поделены на три главные группы. В первую - входили «иностранные рабочие», прибывшие из Западной и Северной Европы. По сравнению с другими они занимали привилегированное положение по условиям труда и быта. Вторая группа состояла из так называемых «восточных рабочих», к которым относились граждане Советского Союза, депортированные с оккупированной вермахтом территории Белоруссии, Молдавии, России и Украины. Они были совершенно бесправны. Третья группа состояла из евреев и цыган, заключенных тюрем и узников концентрационных лагерей. Нацисты отказывали им в праве на жизнь. Они были обречены на уничтожение трудом.

Дифференциация в обращении нацистов с представителями трех названных групп работниц и работников нацистского принудительного труда выражалась в размещении, распределении одежды и продуктов питания, тяжести труда, медицинском обслуживании, возможности свободного передвижения и контактов с немецким населением. Заключенные концентрационных лагерей, переданные СС, сдавались в наем или принуждались к работам непосредственно в лагере, где содержались в условиях особо жесткого трудового режима с высокой долей смертности. Их подневольный труд определяется историками как рабский.

Депортация советских граждан в Германию началась с весны 1942 г. в связи с усиливавшимся дефицитом рабочей силы в рейхе.
По приказу генерального уполномоченного по вопросам труда Фрица Заукеля с апреля по декабрь 1942 г. с оккупированной территории Советского Союза было отправлено около 1,5 млн «восточных рабочих». На чужбину депортировалось население целых деревень, включая семьи с детьми. Возросший приток работников принудительного труда из СССР вызвал в Третьем рейхе опасения за «внутреннюю безопасность» и привел к введению указов о «восточных рабочих» [24]. Доставленных в рейх советских граждан размещали в окруженных колючей проволокой лагерных бараках, а их одежду отмечали нашивкой «OST». Общение с немецким населением им было запрещено. Даже небольшое нарушение предписаний могло закончиться направлением в концентрационный лагерь.

После возвращения на родину бывшие «восточные рабочие» и советские военнопленные не получили признания в качестве жертв войны. Они были обвинены на Родине в сотрудничестве с врагом. И если женщины имели возможность в своем большинстве вернуться в места их прежнего проживания, то мужчины должны были зачастую трудиться в рабочих батальонах в промышленных центрах страны. Офицеры и попавшие под подозрение солдаты могли оказаться в распоряжении ГУЛАГ.

С началом «холодной войны» положение в советском обществе бывших работников нацистского принудительного труда ухудшилось. Судьбы этих людей, драматические страницы их жизненного опыта замалчивались. Лишь после указа президента Российской Федерации Б.Н. Ельцина были восстановлены законные права российских граждан - бывших советских военнопленных и гражданских лиц, репатриированных в годы Великой Отечественной войны и в послевоенный период [12].

Несмотря на появившиеся с тех пор серьезные научные публикации, тема принудительного труда в нацистской Германии все еще нуждается в разработке. Особенно насущно ее исследование в историко-антропологической и гуманитарной перспективе, ибо личный опыт тех, кто пережил это испытание, должен быть сохранен в коллективной памяти и осмыслен последующими поколениями. Цифровая гуманитарная наука позволяет решить 
данную проблему на основе метода устной истории. Представленная статья призвана продемонстрировать варианты практического воплощения вопроса.

Методы. В научной литературе, посвященной проблеме нацистского принудительного труда, по сей день преобладают немецкоязычные исследования. До объединения Германии эта тема являлась прерогативой историков ГДР [16]. В историографии ФРГ особое значение имеет вышедший в 1985 г. фундаментальный труд У. Херберта [21], впервые рассмотревшего политические, идеологические и социально-экономические аспекты проблемы принудительного труда иностранцев в Третьем рейхе.

Волну интереса к теме принудительного труда в Германии вызвала дискуссия 1990-х гг. относительно компенсационных выплат иностранным работникам нацистского принудительного труда. Тогда же в Австрии, в рамках специально созданной комиссии ученых, начался сбор материалов по истории принудительного труда [19], часть которых была обобщена в последующих работах [20; 36].

В объединенной Германии М. Шперер проанализировал накопленный к рубежу XX-XXIвв. опыт зарубежной историографии, сравнив положение иностранных рабочих в различных отраслях экономики рейха [31]. Значительное место занимает фундаментальный труд К. Штрайта, обратившегося к проблеме «восточных рабочих» и советских военнопленных [33].

В СССР бывшие «восточные рабочие» и советские военнопленные, превратившись в «фигуры умолчания», оказались исключены из поля зрения ученых. После распада Сoветского Союза к проблеме принудительного труда сограждан в годы Второй мировой войны обратились белорусские, российские и украинские историки [1]. В России эта тема до сих пор представлена фрагментарно. Следует отметить труды П.М. Поляна [9; 10], в которых комплексно исследованы проблемы советских работников нацистского принудительного труда - судьбы советских военнопленных и «восточных рабочих». В 2016 г. вышла фундаментальная монография В.Н. Земскова, детально осветившего ряд важных вопросов репатриации советских граждан в 1944-1951 годы [5].
В последнее время появилось немало серьезных научных публикаций российских авторов, раскрывающих отдельные аспекты проблемы нацистского принудительного труда [3]. Тем не менее она нуждается в дальнейшем систематическом рассмотрении. Без внимания ученых остались такие важные вопросы, как, например, ресоциализация бывших «восточных рабочих» и советских военнопленных после их возвращения в Советский Союз, путь в неволю советских граждан, модификация у них образа немцев и Германии в результате асимметричной межкультурной коммуникации на чужбине и др.

Очевидно, что проблема принудительного труда иностранцев в нацистской Германии представляет ныне калейдоскоп национальных памятей и интерпретаций этого феномена. Она стала предметом исследования смежных с историей наук, исторической антропологии, психологии, социологии, то есть обрела междисциплинарный характер, что привело к расширению круга источников. Наряду с материалами доступных архивных фондов ${ }^{1}$, личными воспоминаниями бывших работников нацистского принудительного труда $[2 ; 4 ; 7 ; 25 ; 29]$, документами нормативно-правовой базы, периодической печати, исследователи обратились к нарративнобиографическому интервью, которое превратилось в важнейший метод биографических исследований, столь необходимый для разработки проблемы нацистского принудительного труда.

Историки зачастую скептически настроены в отношении устно- исторических источников. Они указывают на неточности в интервью как источнике, созданном намного позже случившихся событий. Даты и сведения географического характера выглядят в воспоминаниях очевидцев иногда беспорядочно, что приводит к снижению ценности этих свидетельств для историков. Тем не менее воспоминания являются зачастую единственным историческим источником, в котором тематизируются особые исторические события, получают слово личности или группы лиц, не оставившие иных свидетельств, находятся ответы на вопросы «почему» и «зачем», которые редко раскрываются другими историческими источниками [15]. 
Действительно, созданные в рамках устной истории источники следует использовать с осторожностью. Свое воздействие на воспоминания очевидца оказывают: совокупная жизненная история рассказчика; факты и интерпретации, узнанные им позже изучаемого события, или периода, например, из прессы; социокультурная и политическая обстановка; окружение респондента. Все это надо учитывать [22]. Но критически следует относиться и к другим источникам, например, к мемуарам известных личностей и даже к письменным источникам, ибо и они не содержат абсолютной истины, но всегда связаны с контекстом.

В процессе интервью создается не только исторический источник. Очевидцы получают, кроме того, возможность посредством интервью дать показания, на письменную фиксацию которых у них не было бы иначе ни возможностей, ни сил. Знакомый предлагал М.И. Виткевич записать ее воспоминания и, таким образом, внести свой вклад в книгу, но она объяснила: «У меня никогда не дойдут до этого руки, во-первых, мне всегда некогда, и потом это такое дело. В этом году у меня хуже со здоровьем, чем в прошлом, и как только я начинаю писать, у меня начинаются проблемы с сердцем. Наконец, ...я принимаю все слишком близко к сердцу и когда разговариваю сейчас с Вами, ведь все это происходило со мной. Все эти вещи, от начала до конца. Когда я говорю, я переживаю все это снова, это очень тяжело. Я, может быть, не подаю вида, но мои щеки горят, да» [6].

Традиционные и новые методы исторического исследования не противоречат друг другу. Возможность применения учеными интервью предоставляют онлайн-коллекции интервью.

Нынче существует множество устноисторических коллекций с самыми разными содержательными акцентами. Интервью записывались в соответствии с техническими возможностями времени. Сначала это были только конспекты, с 1940-х гг. появились записи воспоминаний на магнитофон, позже-кино- и видеосъемка. Наряду с формой записи изменилось и обеспечение интервью. Если раньше исследователи могли воспользоваться интервью только в архивах, то теперь это стало возможно онлайн, то есть в любое время и в любом месте. Интервью доступны как для ученых, так и для заинтересованных представителей общественности [27]. В качестве примера может служить Visual History Archive des Shoah Foundation Institute университета Южной Каролины, который содержит около 52000 интервью с очевидцами Холокоста и является самым большим в мире онлайн-архивом. Следует упомянуть также онлайн-архив «Говорить, несмотря ни на что» [32] или онлайн-архив Европейского Сопротивления [17].

Анализ. В данной статье предметом исследования является онлайн-архив «Принудительный труд 1939-1945. Воспоминания и история» [37] и связанная с ним онлайн-платформа. Онлайн-архив включает коллекцию около 600 биографических интервью с теми, кто против своей воли должен был работать на Третий рейх. Интервью состоялись на 25 языках в 26 странах. Из них 82 были проведены в Украине и 70 - в России. Большая часть интервью в коллекции русскоязычные, их 123 . Это соответствует значительному участию русскоязычного населения СССР, привлекавшегося к принудительному труду в нацистской Германии.

История возникновения данного проекта связана с проблемой компенсационных выплат работникам принудительного труда. Оказалось, что каждый четвертый рабочий в нацистской Германии являлся иностранным работником принудительного труда, встретить которого можно было практически в любом населенном пункте. В годы Второй мировой войны почти во всех немецких семьях использовались работники или работницы принудительного труда. До сих пор в Германии много зданий, дорог, аэропортов, созданных иностранными рабочими - невольниками Третьего рейха. «Кто думает о том, когда пьет воду из крана, что вода поступает из водохранилища, которое было построено немецкими евреями, французами из вишистской Франции или польскими военнопленными?» [35] - спрашивает известный немецкий ученый А. фон Плато. Тем не менее совершенная по отношению к работникам принудительного труда несправедливость в Германии долгое время не обсуждалась и не признавалась. Они не получили сначала и компенсацию. 


\section{ВСЕОБЩАЯ ИСТОРИЯ}

В Германской Демократической Республике считалось, что созданное после крушения Третьего рейха государство не несет никаких обязательств по отношению к жертвам нацизма. Федеративная Республика Германия рассматривала претензии на компенсацию как претензии на репарации, которые не могли быть востребованы без мирного договора с Германией союзников по Антигитлеровской коалиции ${ }^{2}$. Таким образом, лишь некоторые страны получили компенсации в рамках глобальных соглашений ${ }^{3}$.

Только в августе 2000 г. был основан фонд «Память, ответственность и будущее». В его задачу входила выплата компенсаций бывшим работникам принудительного труда и, следовательно, окончательное урегулирование финансовых претензий бывших невольников Третьего рейха. Это создавало правовую гарантию, особенно для утверждавшегося и расширявшегося в США немецкого бизнеса, опасавшегося совокупных исков бывших работников принудительного труда. Для выплаты компенсаций фонд располагал суммой в 10 миллиардов немецких марок, сложившейся из равных частей - государства и бизнеса. Официально выплаты были завершены 12 июня 2007 года. Представленная ниже таблица фонда демонстрирует объем состоявшихся выплат [34] (см. таблицу).

Три критерия были основополагающими для определения суммы, которую получал бывший работник или работница принудитель- ного труда: а) место и условия вынужденного проживания; б) тяжесть принудительного труда; в) факт депортации.

Минимальная сумма составляла 2500 евро, максимальная - 7670 евро [13].

Компенсационные выплаты были завершены в 2007 году. Далеко не все бывшие работники принудительного труда до них дожили. Не получили компенсации западноевропейские рабочие, избежавшие заключения в концентрационных лагерях, итальянские военные интернированные, советские военнопленные ${ }^{4}$.

После окончания выплат фонд «Память, ответственность и будущее» начал вкладывать оставшиеся средства в действующие и ныне проекты в соответствии с темами: «Толкование истории», «Действовать в защиту прав человека» и «Обязательства ради жертв национал-социализма». Цель этого направления в работе фонда заключается в сохранении истории национал-социалистического принудительного труда в европейской культуре памяти, а также поддержка его жертв. Исходя из этой цели фонд инициировал среди прочего устноисторический проект «Принудительный труд 1939-1945», который проходил в два этапа.

На первом этапе, в 2005-2006 гг., были проведены интервью. Институт истории и биографии Хагенского заочного университета координировал работу 32 партнерских групп из 26 стран $^{5}$. Сотрудники этих групп вели биографические интервью с бывшими

Таблийа

\begin{tabular}{|l|c|c|}
\hline \multicolumn{1}{|c|}{ Партнерские организации } & Число получателей & Сумма выплат в евро \\
\hline Беларусь: & 129000 & $345 \mathrm{млн}$ \\
Из них: & 120000 & 324 млн \\
- Беларусь & 9000 & 21 млн \\
- Эстония & 90000 & 386 млн \\
\hline Международная организация по вопросам миграции (IOM) & 159000 & 1149 млн \\
\hline Конференция еврейских претензий (ЈСС) & 484000 & 979 млн \\
\hline Польша & 256000 & 426 млн \\
\hline Россия: & & \\
Из них: & 228000 & 380 млн \\
- Россия & 13000 & 23 млн \\
- Латвия & 12000 & 18 млн \\
- Литва & 3000 & 5 млн \\
- Другие государства СНГ & 76000 & 210 млн \\
\hline Чехия & 471000 & 867 млн \\
\hline Украина & 1665000 & 4362000000 \\
\hline Всего & & \\
\hline
\end{tabular}


работниками принудительного труда под руководством немецкого историка, профессоpa А. фон Плато [28]. О своей судьбе рассказывали бывшие заключенные концентрационных лагерей, гражданские работники принудительного труда, военнопленные, а также цыгане или германизированные дети. При опросах обращалось внимание на репрезентативность различных групп жертв.

Интервью состоялись с 341 мужчиной и 249 женщинами, семь бесед были проведены с парами. Встречи длились в среднем три с половиной часа. Респонденты рассказывали о своей жизни, при этом годы до и после принудительного труда получили также свое отражение. После долгого повествования респондента следовали уточняющие вопросы интервьюера. 190 интервью были сняты на видео. Оставшиеся 393 - аудиозаписи. Все они были дополнены таблицами с данными респондента, протоколами, краткими биографиями, копиями документов и фотографий из его личного архива. Интервью транскрибировались и переводились на немецкий язык ${ }^{6}$.

Второй этап проекта начался в конце 2008 года. Он включал архивирование, обработку и презентацию интервью. Изготавливались образовательные материалы. Германский исторический музей заархивировал около 2000 аудио- и видеопленок, после чего они были оцифрованы Центром цифровых систем Свободного университета г. Берлин ${ }^{7}$. При этом состоялся переход в высококачественные, относительно «большие» цифровые форматы, на основе которых создавались копии для работы и общественной презентации. В дальнейшем они переводились в цифровой формат, меняющийся вместе с техническим прогрессом. Копии архивировались в вычислительном центре (ZEDAT) Свободного университета г. Берлин.

Центр цифровых систем взял на себя и решение задач, суть которых заключалась в обработке и предоставлении материалов интервью пользователям.

Следующим шагом стало научное осмысление представленных интервью ${ }^{8}$. Эта возможность определяется онлайн-предложением в виде сайта и архива интервью.

В настоящее время сайт существует на четырех языках: немецком [37], английс- ком [18], русском [11] и чешском [26]. Он разделен на доступную (без регистрации) часть с контекстной информацией о принудительном труде, компенсационных выплатах, с рекомендациями литературы и собственно архив интервью, в который можно войти, зарегистрировавшись. Регистрация необходима, ибо пользователи обязуются при этом придерживаться соответствующих правил, прежде всего, признают личные права респондентов.

Русскоязычная версия онлайн-архива «Принудительный труд 1939-1945. Воспоминания и история» доступна российским пользователям с конца 2014 года. Она призвана способствовать внедрению индивидуального опыта в общественное сознание и модификации коллективной памяти России относительно бывших работников нацистского принудительного труда.

Появление онлайн-архива сделало возможным решение ряда важных проблем: он позволял донести тему нацистского принудительного труда до молодежи, сохранить в памяти россиян жизненную трагедию бывших работников принудительного и рабского труда, историю их насильственного угона в Германию, эксплуатации, жизни после возвращения в Советский Союз. Но использование онлайн-архива интервью требовало времени, на которое не может рассчитывать на уроке учитель. Как в таком случае побудить молодых людей заниматься данной проблемой?

Эту задачу пытается решить российская версия онлайн-платформы «Обучение на основе интервью. Принудительный труд 19391945» [8]. Она предназначена, прежде всего, для средней школы. Над созданием платформы работал действующий в структуре Воронежского института высоких технологий Научно-образовательный центр устной истории в сотрудничестве с Центром цифровых систем Свободного университета г. Берлин, при поддержке фонда «Память, ответственность и будущее» ${ }^{9}$.

Российская платформа представлена шестью краткими биографическими фильмами (до 30 мин), созданными на основе избранных видеоинтервью онлайн-архива «Принудительный труд 1939-1945». Три фильма посвящены судьбе россиян: еврею И.И. Абковичу, пережившему трагедию Хо- 
локоста и заключение в нацистском концентрационном лагере Аушвиц-Биркенау; бывшей «восточной рабочей» О.И. Смирновой, прошедшей через концентрационный лагерь $\mathrm{Pa}$ венсбрюк; бывшему советскому военнопленному М.П. Бочкареву, заключенному нескольких концентрационных лагерей, включая Бухенвальд. Вторая половина платформы знакомит с судьбой немки Элизабет Кунеш, которая после заключения в Равенсбрюке была исключена из так называемого «народного сообщества». Полон драматизма и фильм, посвященный польке Анне Паларчик, узнице концентрационного лагеря АушвицБиркенау, свидетельствовавшей на Франкфуртском процессе 1960-х годов. Жизненная история француза - Виктора Лавиля - призвана продемонстрировать противоправность нацистской политики принудительного труда на территории оккупированной Франции.

Таким образом, российские старшеклассники получат возможность не только познакомиться с судьбами их соотечественников, каждый из которых относится к одной из многочисленных групп советских жертв войны, остававшихся долгое время за пределами внимания общества и науки. Они смогут осознать масштабы и многообразие форм принудительного труда, практиковавшегося нацистами в годы Второй мировой войны в качестве меры репрессивного воздействия на население Германии и оккупированной части Европы, с одной стороны, и способ решения проблемы рабочих рук для немецкой экономики, с другой. Представленные фильмы демонстрируют специфику положения названных групп работников нацистского принудительного труда и, следовательно, разные шансы на их выживание. «Труд на уничтожение» еврея И.И. Абковича, рабский труд заключенных концентрационных лагерей, советских военнопленных, принудительный труд «восточных рабочих», иностранных рабочих из стран Западной Европы - все это может быть осмыслено в старших классах средней школы с учетом комплекса вопросов, разработанных к каждому биографическому фильму.

Эти вопросы объединены в трех разделах. В первом разделе акцент делается на знакомстве обучающихся с биографическим фильмом, во втором вопросы сформулирова- ны так, чтобы выявить характер принудительного труда и связанные с ним условия жизни в неволе. Большое внимание уделяется проблеме Сопротивления нацизму и солидарности товарищей по несчастью независимо от их национально-государственной принадлежности. Во всех представленных на платформе фильмах повествуется о жизни после освобождения и окончания войны. Предлагаемые к данному периоду истории вопросы позволят проследить трудности жизни советских репатриантов в условиях сталинского и постсталинского СССР. В этом разделе обязательно присутствуют вопросы, связанные с местом представителя данной группы жертв войны в культуре памяти России или страны его/ее происхождения.

В третьем комплексе вопросов подчеркивается особенность нарративно-биографического интервью. Внимание обучающихся привлекается к онлайн-архиву «Принудительный труд 1939-1945» как к возможности аналитического сравнения биографического фильма с полным интервью и выявления принципов конструирования различных нарративов.

В работе над вопросами к биографическим фильмам обучающиеся могут опираться на материалы платформы. В российской версии они содержат источники, которые впервые вводятся в оборот. Это, прежде всего, фотографии или копии документов из архивов мемориальных комплексов: АушвицБиркенау (Республика Польша), Яд Вашем (Израиль), Берген-Бельзен (ФРГ), архива Международной службы поиска в Бад Арользен (ФРГ), Государственного архива Российской Федерации, Липецкого областного краеведческого музея, Государственного архива Воронежской области, Государственного архива общественно-политической истории Воронежской области, личных архивов граждан России, Польши и пр.

Платформа дополнена контекстным фильмом, посвященным проблеме нацистского принудительного труда и его месту в культуре памяти России и Европы, а также хронологической таблицей и словарем.

В 2018 г. началось распространение в России онлайн-архива интервью и связанной с ним онлайн-платформы «Обучение на основе интервью». Претворение этой задачи в 
жизнь взяли на себя несколько высших учебных заведений - Елецкий государственный университет, Курский государственный университет, Ярославский государственный педагогический университет, Волгоградский государственный социально-педагогический университет и др. В качестве координатора проекта выступает Научно-образовательный центр устной истории Воронежского института высоких технологий. В соответствии с подписанным соглашением поддержку оказывают Институт всеобщей истории Российской академии наук и Германский исторический институт в Москве.

Использование онлайн-платформы обеспечивает системе среднего образования России современную основу коммуникации учителя и ученика. Благодаря новым видеотехнологиям у российской молодежи появляется ощущение сопричастности судьбам бывших советских работников принудительного труда в нацистской Германии, что особенно важно тем, в чьих семьях оказался не востребован опыт уходящего поколения переживших войну и неволю.

Результаты. С начала 1990-х гг. тема использования принудительного труда в Третьем рейхе, до этого достаточно широко разработанная, главным образом в Германии, вышла на новый уровень исследования. Она стала междисциплинарной. Особую значимость приобрела историко-антропологическая и гуманитарная направленность ее изучения. Современные научные подходы к данной проблеме наряду с традиционными методами исследования базируются на использовании цифровой гуманитарной наукой метода устной истории. Конкретным воплощением данной тенденции стали представленные в данной статье онлайн-архив интервью «Принудительный труд 1939-1945. Воспоминания и история» и связанная с ним онлайн-платформа «Обучение на основе интервью. Принудительный труд 1939-1945». Онлайн-архив и образовательная онлайн-платформа являются важным историческим источником о принудительном труде как важном элементе национал-социалистического господства. Они позволяют сделать проблему жертв нацистского принудительного труда более зримой в европейской и российской культурах памяти.

\section{ПРИМЕЧАНИЯ}

${ }^{1}$ См., например: Государственный архив Российской Федерации. Ф. Р-9526. Управление Уполномоченного совнаркома СССР - Совета Министров СССР по делам репатриации, 1944-1952 ; Фонд Р-327. Переселенческое управление при Совете Министров РСФСР. Отдел по репатриации и реэвакуации советских граждан ; Фонд Р-9437. Уполномоченный особого комитета при СМИД по Германии (1945-1947).

2 Лондонский договор 1953 г. остановил процесс выплаты Германией репараций, отложив его до подписания мирного договора, которое так и не состоялось.

3 Выплаты в рамках глобальных соглашений были совершены в 1952 г. Израилю, в 1959 г. и 1964 г. - ряду западноевропейских стран, в 1990 г. Польше и бывшим республикам Советского Союза.

${ }^{4}$ Решение немецкого правительства о выплате символической компенсации бывшим советским военнопленным в нацистской Германии было принято только в 2015 году [14].

5 В России работали несколько групп: одна группа представляла Российскую академию наук, две - Международное общество «Мемориал», четвертая группа - аспирантов и студентов Воронежского государственного педагогического университета - действовала под руководством кандидата исторических наук Н.П. Тимофеевой, одного из авторов этой статьи.

6 Транскрибирование интервью и перевод всех видеоинтервью были осуществлены уже на первом этапе проекта. На втором этапе в институте Восточной Европы Свободного университета г. Берлин под руководством профессора Гертруд Пикан состоялось редактирование 400 транскрибированных текстов и всех сделанных ранее переводов, продолжалась работа над переводом. В общей сложности были переведены 400 интервью.

7 Копии интервью оставались также у партнерских центров в тех странах, где проводились интервью, и в Хагенском университете.

8 Это предполагало соотнесение метаданных, переработку кратких биографий, разделение интервью посредством заглавий и подзаголовков, комментирование редакционных примечаний, а также составление регистра записей. Все данные в интервью - географические наименования, фирмы, лагеря и имена - были учтены и дополнены географическими координатами, псевдонимами и т. д. Была создана и редакционная система. Появившиеся в ней данные переносились через функцию экспорта в онлайн-архив.

9 Фонд «Память, ответственность и будущее» поддержал также создание онлайн-платформы «Обу- 
чение на основе интервью» в ФРГ [23] и Чехии [30]. В основе каждой версии лежала своя концепция с учетом национальной истории нацистского принудительного труда в годы Второй мировой войны.

\section{СПИСОК ЛИТЕРАТУРЫ}

1. Белорусские остарбайтеры: историко-аналитическое исследование / Г. Д. Кнатько, В. И. Адамушко [и др.]. - Минск : НАРБ, 2001. - 336 с.

2. Вербицкий, Г. Г. Почта остарбайтеров Второй мировой войны: документы и переписка / Г. Г. Вербицкий. - Hermitage publishers, 1996. - 232 c.

3. Данченко, Е. Л. Батраки поневоле. Принудительный труд «восточных рабочих» в сельском хозяйстве нацистской Германии (1941-1945) / Е. Л. Данченко. - Воронеж : Изд-во Воронеж. гос. пед. ун-та, 2012. $-168 \mathrm{c}$.

4. Джерела пам'яті: Історико-краэзнавчий альманах. Вип. 2. Остарбайтери: живая правда живий біль / упорядник Т. Ю. Нагайко. - Переяслав-Хмельницкий, 2010. - 457 с.

5. Земсков, В. Н. Возвращение советских перемещенных лиц в СССР. 1944-1952 гг. / В. Н. Земсков. - М. : Ин-т рос. истории Рос. акад. наук, 2016. $424 \mathrm{c}$.

6. Интервью с бывшей «восточной рабочей» М.И. Виткевич. - Электрон. текстовые дан. - Режим доступа: https://zwangsarbeit-archiv.de/archiv/ interviews/za343?locale=ru (дата обращения: 25.10.2018). - Загл. с экрана.

7. Люлькина, Е. И. Война и украденные годы: живые свидетельства остарбайтеров Беларуси / Е. И. Люлькина. - Минск : Издатель Логвинов И.П., 2009. - 264 с.

8. Обучение на основе интервью. Принудительный труд. 1939-1945. Воспоминания и история. - Электрон. текстовые дан. - Режим доступа: https://obuchenie-na-osnove-intervyu.org/ (дата обращения: 25.10.2018). - Загл. с экрана.

9. Полян, П. М. Жертвы двух диктатур. Жизнь, труд, унижения и смерть советских военнопленных и остарбайтеров на чужбине и на родине / П. М. Полян. - М. : РОССПЭН, 2002. - 978 с.

10. Полян, П. М. Жертвы двух диктатур. Остарбайтеры и военнопленные в Третьем рейхе и их репатриация / П. М. Полян. - М. : Ваш выбор ЦИРЗ, 1996. -442 c.

11. Принудительный труд 1939-1945. Воспоминания и история. - Электрон. текстовые дан. Режим доступа: https:/www.zwangsarbeit-archiv.de/ ru/index.html/ (дата обращения: 25.10.2018). - Загл. с экрана.

12. Указ Президента Российской Федерации от 24.01.1995 г. № 63 «О восстановлении законных прав российских граждан - бывших советских военнопленных и гражданских лиц, репатриированных в период Великой Отечественной войны и в послевоенный период». - Электрон. текстовые дан. - Режим доступа: http://www.kremlin.ru/acts/bank/7453. (дата обращения: 03.102018). - Загл. с экрана.

13. Фрайтаг, Г. Принудительные работы при национал-социализме 60 лет спустя. Работа Фонда «Память, ответственность и будущее» / Г. Фрайтаг // Память о войне 60 лет спустя: Россия, Германия, Европа. - М. : Новое литературное обозрение, 2005. - C. 314-329.

14. Anerkennungsleistung an ehemalige sowjetische Kriegsgefangene. - Electronic text data. Mode of access: https://www.badv.bund.de/DE/ OffeneVermoegensfragen/Anerkennungsleistung SowjetischeKriegsgefangene/start.html/(Zugangsdatum 28 Oktober 2018). - Title from screen.

15. Es gilt das gesprochene Wort. Oral History und Zeitgeschichte heute / eds.: K. Andresen, L. Apel, K. Heinsohn. - Göttingen : Wallstein, 2015. - 224 S.

16. Eichholtz, D. Geschichte der deutschen Kriegswirtschaft 1939-1945. Bd. I: 1939-1941 /D. Eichholtz. - Berlin :Akademie-Verlag, 1971.-398 S.

17. European resistance archive. - Electronic text data. - Mode of access: http://www.resistancearchive.org/ (Zugangsdatum 15 Oktober 2018). - Title from screen.

18. Forsed labor 1939-1945. Memory and histori. - Electronic text data. - Mode of access: http:/ /www. zwangsarbeit-archiv.de/en/index.html (Zugangsdatum 15 Oktober 2018). - Title from screen.

19. Gedächtnis und Gegenwart Historiker Innenkommissionen. Politik und Gesellschaft. Electronic text data. - Mode of access: http://www. politischebildung.com/pdfs/20_printversion.pdf (Zugangsdatum 22 Oktober 2018). - Title from screen.

20. Industrie und Zwangsarbeit im Nationalsozialismus / G. Hauch (Hg.). - Innsbruck; Wien; München; Bozen : Studien Verlag, 2003. - 252 S.

21. Herbert, U. Politik und Praxis des "Ausländer-Einsatzes" in der Kriegswirtschaft des Dritten Reiches / U. Herbert. - Berlin; Bonn : Dietz, 1985. - 494 S.

22. Leh, A. Vierzig Jahre Oral History in Deutschland. Beitrag zu einer Gegenwartsdiagnose von Zeitzeugenarchiven am Beispiel des Archivs "Deutsches Gedächtnis" / A. Leh // Westfälische Forschungen. Zeitschrift des LWL-Instituts für westfälische Regionalgeschichte. - 2015. - № 65. -S. 255-268.

23. Lernen mit Interviews: Zwangsarbeit 19391945. - Electronic text data. - Mode of access: https:/ /lernen-mit-interviews.de/ (Zugangsdatum 15 Oktober 2018). - Title from screen.

24. Merkblatt zum Einsatz der Zivilarbeiter und Arbeiterinnen aus dem sowjetischen Gebiet in der 
Landwirtschaft. 21. Juli 1942 // StAMS. Politische Polizei. - № 366 .

25. «Nepřicházi-Li prácek Tobě...» («Kommt die Arbeit nicht zu Dir»). - Praha, 2003. - 406 s.

26. Nucená práce 1939-1945. Vzpomínky a dějiny. - Electronic text data. - Mode of access: https://www. zwangsarbeit-archiv.de/cs/index.html / (Zugangsdatum 2 Oktober 2018). - Title from screen.

27. Pagenstecher, C. Learning with Digital Testimonies in Germany. Educational Material on Nazi Forced Labor and the Holocaust / C. Pagenstecher, D. Wein // Eds.: Llewellyn K., Ng-A-Fook N. Oral History and Education. Theories, Dilemmas, and Practices. - 2017. - P. 361-378. - Electronic text data. Mode of access: https://www.palgrave.com/ us/book/ 9781349950188 (Zugangsdatum 5 Oktober 2018). - Title from screen.

28. Plato, A. von. Hitler's Slaves. Life Stories of Forced Labourers in Nazi-Occupied Europe / A. Plato von, A. Leh \& C. Thonfeld (Eds.). - N. Y. : Berghahn Books, 2010. -560 p.

29. Praca przymusowa. Niemcy, robotnicy przymusowi i wojna. - Weimar, 2013. - $24 \mathrm{~s}$.

30. Př́iběhy pamětníkù ve výuce. - Electronic text data. - Mode of access: https://nucenaprace.cz/ (Zugangsdatum 21 Oktober 2018). - Title from screen.

31. Spoerer, M. Zwangsarbeit unter dem Hakenkreuz: ausländische Zivilarbeiter, Kriegsgefangene und Häftlinge im Deutschen Reich und im besetzten Europa. 1939-1945 / M. Spoerer. - Stuttgart; München : Dt.Verl.-Anst., 2001.-332 S.

32. Sprechen trotz allem. Lebensgeschichtliche Interviews der Stiftung Denkmal für die ermordeten Juden Europas. - Electronic text data. - Mode of access: http://www.sprechentrotzallem.de/ (Zugangsdatum 21 Oktober 2018). - Title from screen.

33. Streit C. Keine Kameraden: Die Wehrmacht und die sowjetischen Kriegsgefangenen 1941-1945. Bonn : Verlag J.H.W. Dietz Nachf. GmbH, 1991. - 448 S.

34. Zahlen und Fakten zur Fördertätigkeit. Electronic text data. - Mode of access: http:// www.stiftung-evz.de/stiftung/zahlen-und-fakten.html (Zugangsdatum 21 Oktober 2018). - Title from screen.

35. Zur Diskussion. Zugänge zum Thema Zwangsarbeit. - Electronic text data. - Mode of access: http://lernen-aus-der-geschichte.de /Lernenund-Lehren / content / 8726/2010-08-31-Zugaenge$\% 20$ zum-Thema-Zwangsarbeit (Zugangsdatum 21 Oktober 2018). - Title from screen.

36. Zwangsarbeiter in Österreich 1939-1945 und ihre Nachkriegsschicksale / D. Bacher, St. Karner (Hg.). Innsbruck; Wien; Bozen : Studien Verlag, 2013. - 352 S.

37. Zwangsarbeit 1939-1945. Erinnerungen und Geschichte. - Electronic text data. - Mode of access: https://www.zwangsarbeit-archiv.de/ (Zugangsdatum 23 Oktober 2018). - Title from screen.

\section{REFERENCES}

1. Knatko G.D., Adamushko V.I., et al. Belorusskie ostarbaytery: istoriko-analiticheskoe issledovanie [Belarusian Ostarbeiters: Historical and Analytical Research]. Minsk, NARB Publ., 2001.336 p.

2. Verbitskiy G.G. Pochta ostarbayterov Vtoroy mirovoy voyny: dokumenty i perepiska [Mail of Ostarbeiters of World War II: Documents and Correspondence]. Hermitage publishers, 1996. 232 p.

3. Danchenko E.L. Batraki ponevole. Prinuditelnyy trud «vostochnykh rabochikh»v selskom khozyaystve natsistskoy Germanii (1941-1945) [Farm Laborers against Their Will. Forced Labor of "East Workers" in Agriculture of Nazi Germany (1941-1945)]. Voronezh, Izd-vo Voronezh. gos. ped. un-ta, 2012. 168 p.

4. Nagaiko T.Yu. Dzherela pamyati: Istorikokraeznavchiy almanakh. Vip. 2. Ostarbayteri: zhivaya pravda - zhiviy bil [Sources of Memory: Historical and Regional Almanac. Iss. 2. Ostarbeiter: the Living Truth is Alive]. Pereyaslav-Khmelnytsky, 2010. 457 p.

5. Zemskov V.N. Vozvrashchenie sovetskikh peremeshchennykh lits v SSSR. 1944-1952 gg. [Return of the Soviet Displaced Persons to the USSR. 1944-1952]. Moscow, In-t ros. istorii Ros. akad. nauk, 2016. 424 p.

6. Intervyu s byvshey "vostochnoy rabochey» M.I. Vitkevich [Interview with the Former "East Worker" M. I. Vitkevich]. URL: https://zwangsarbeitarchiv.de/ archiv/interviews/za343?locale=ru (accessed 25 October 2018).

7. Lyulkina E.I. Voyna i ukradennye gody: zhivye svidetelstva ostarbayterov Belarusi [War and the Stolen Years: Live Certificates of Ostarbeiters of Belarus]. Minsk, Logvinov I.P. Publ., 2009. 264 p.

8. Obuchenie na osnove intervyu. Prinuditelnyy trud. 1939-1945. Vospominaniya i istoriya [Training on the Basis of Interview. Forced Labor in 1939-1945. Memoirs and History]. URL: https://obuchenie-naosnove-intervyu.org https://obuchenie-na-osnoveintervyu.org/ (accessed 25 October 2018).

9. Polyan P.M. Zhertvy dvukh diktatur. Zhizn, trud, unizheniya i smert sovetskikh voennoplennykh $i$ ostarbayterov na chuzhbine $i$ na rodine [Victims of Two Dictatorships: Life, Work, Humiliations and Death of the Soviet Prisoners of War and Ostarbeiters in the Foreign Land and in the Homeland]. Moscow, ROSSPEN Publ., 2002.978 p.

10. Polyan P.M. Zhertvy dvukh diktatur. Ostarbaytery $i$ voennoplennye $v$ Tretem reyhe $i$ ikh repatriatsiya [Victims of Two Dictatorships. Ostarbeiters and Prisoners of War in the Third Reich and Their Repatriation]. Moscow, Vash vybor TSIRZ, 1996. 442 p.

11. Prinuditelnyy trud 1939-1945. Vospominaniya $i$ istoriya [Forced Labor in 1939-1945. Memoirs and 
History]. URL: https:/www.zwangsarbeit-archiv.de/ ru/index.html/ (accessed 25 October 2018).

12. Ukaz Prezidenta Rossiyskoy Federatsii ot 24.01.1995 g. № 63 «O vosstanovlenii zakonnykh prav rossiyskikh grazhdan - byvshikh sovetskikh voennoplennykh i grazhdanskikh lits, repatriirovannykh $v$ period Velikoy Otechestvennoy voyny i v poslevoennyy period» [Decree of the President of the Russian Federation of 24 January 1995 No. 63 'About Recovery ofLegitimate Rights of the Russian Citizens - the Former Soviet Prisoners of War and Civilians Repatriated in the Period of the Great Patriotic War and During the Post-War Period']. URL: http://www .kremlin.ru/acts/bank/ 7453. (accessed 3 October 2018).

13. Fraytag G. Prinuditelnye raboty pri natsionalsotsializme 60 let spustya. Rabota Fonda «Pamyat, otvetstvennost i budushchee» [Forced Labor at National Socialism 60 Years Later. Work of the Fund Memory, Responsibility and Future]. Pamyat o voyne 60 let spustya: Rossiya, Germaniya, Evropa [Memory of War 60 years Later: Russia, Germany, Europe]. Moscow, Novoe literaturnoe obozrenie Publ., 2005, pp. 314-329.

14. Anerkennungsleistung an ehemalige sowjetische Kriegsgefangene. URL: https://www. badv.bund.de/DE/OffeneVermoegensfragen/ Anerkennungsleistung SowjetischeKriegsgefangene/ start.html/( accessed 28 October 2018).

15. Andresen K., Apel L., Heinsohn K., eds. Es gilt das gesprochene Wort. Oral History und Zeitgeschichte heute. Göttingen, Wallstein, 2015. $224 \mathrm{p}$.

16. Eichholtz D. Geschichte der deutschen Kriegswirtschaft 1939-1945. Bd. I: 1939-1941. Berlin, Akademie-Verlag, 1971.398 p.

17. European resistance archive. URL: http:// www.resistance-archive.org/ (accessed 25 October 2018).

18. Forced labor in 1939-1945. Memory and history. URL: http://www. zwangsarbeit-archiv.de/en/ index.html (accessed 15 October 2018).

19. Gedächtnis und Gegenwart Historiker Innenkommissionen. Politik und Gesellschaft. URL: http:/ /www. politischebildung.com/pdfs/20 printversion.pdf (accessed 22 October 2018).

20. Hauch G., ed. Industrie und Zwangsarbeit im Nationalsozialismus. Innsbruck; Wien; München; Bozen, Studien Verlag, 2003.252 p.

21. Herbert U. Politik und Praxis des “Ausländer-Einsatzes" in der Kriegswirtschaft des Dritten Reiches. Berlin; Bonn, Dietz, 1985. 494 p.

22. Leh A. Vierzig Jahre Oral History in Deutschland. Beitrag zu einer Gegenwartsdiagnose von Zeitzeugenarchiven am Beispiel des Archivs "Deutsches Gedächtnis". Westfälische Forschungen.
Zeitschrift des LWL-Instituts für westfälische Regionalgeschichte, 2015, no. 65, pp. 255-268.

23. Lernen mit Interviews: Zwangsarbeit 19391945. URL: https://lernen-mit-interviews.de/ (accessed 15 October 2018).

24. Merkblatt zum Einsatz der Zivilarbeiter und Arbeiterinnen aus dem sowjetischen Gebiet in der Landwirtschaft. 21. Juli 1942. StAMS. Politische Polizei, no. 366 .

25. «Nepřicházi-Li práce k Tobě...» («Kommt die Arbeit nicht zu Dir»). Praha, 2003. 406 p.

26. Nucená práce 1939-1945. Vzpomínky a dějiny. URL: https://www. zwangsarbeit-archiv.de/cs/ index.html/ (accessed 2 October 2018).

27. Pagenstecher C., Wein D. Learning with Digital Testimonies in Germany. Educational Material on Nazi Forced Labor and the Holocaust. Llewellyn K., Ng-A-Fook N., eds. Oral History and Education. Theories, Dilemmas, and Practices, 2017, pp. 361378. URL: https://www.palgrave.com/ us/book/ 9781349950188 (accessed 5 October 2018).

28. Plato A. von, Leh A., Thonfeld C., eds. Hitler's Slaves. Life Stories of Forced Labourers in Nazi-Occupied Europe. New York, Berghahn Books, 2010.560 p.

29. Praca przymusowa. Niemcy, robotnicy przymusowi $i$ wojna. Weimar, 2013. 24 p.

30. Přiběhy pamětnikù ve výuce. URL: https:// nucenaprace.cz/ (accessed 21 October 2018).

31. Spoerer M. Zwangsarbeit unter dem Hakenkreuz: ausländische Zivilarbeiter, Kriegsgefangene und Häftlinge im Deutschen Reich und im besetzten Europa. 1939-1945. Stuttgart; München, Dt.Verl.-Anst., 2001. 332 p.

32. Sprechen trotz allem. Lebensgeschichtliche Interviews der Stiftung Denkmal für die ermordeten Juden Europas. URL: http://www.sprechentrotzallem.de/ (accessed 21 October 2018).

33. Streit C. Keine Kameraden: Die Wehrmacht und die sowjetischen Kriegsgefangenen 1941-1945. Bonn, Verlag J.H.W. Dietz Nachf. GmbH, 1991.448 p.

34. Zahlen und Fakten zur Fördertätigkeit. URL: http://www.stiftung-evz.de/stiftung/zahlen-undfakten.html (accessed 21 October 2018).

35. Zur Diskussion. Zugänge zum Thema Zwangsarbeit. URL: http://lernen-aus-der-geschichte.de /Lernen-und-Lehren/content/8726/2010-08-31Zugaenge-\%20zum-Thema-Zwangsarbeit (accessed 21 October 2018).

36. Bacher D., Karner St., eds. Zwangsarbeiter in Österreich 1939-1945 und ihre Nachkriegsschicksale. Innsbruck; Wien; Bozen, Studien Verlag, 2013. 352 p.

37. Zwangsarbeit 1939-1945. Erinnerungen und Geschichte. URL: https://www.zwangsarbeitarchiv.de/ (accessed 23 October 2018). 


\section{Information about the Authors}

Doris Tausendfreund, Doctor of History, Center für Digitale Systeme, Freie Universität Berlin, Ihnestraße, 24, 14195 Berlin, Germany, doris.tausendfreund@fu-berlin.de, https://orcid.org/0000-00032211-399X

Natalya P. Timofeeva, Candidate of Sciences (History), Head of Educational and Research Center for Oral History, Voronezh Institute of High Technologies, Lenina St., 73a, 394043 Voronezh, Russian Federation, timnp@mail.ru, https://orcid.org/0000-0002-5368-6144

Tatyana V. Evdokimova, Doctor of Sciences (History), Professor, Head of Department of World History and Methods of Teaching History and Social Science, Volgograd State Socio-Pedagogical University, Prosp. Lenina, 27, 400066 Volgograd, Russian Federation, eva_tan@mail.ru, https://orcid.org/ 0000-0003-0017-1363

\section{Информация об авторах}

Дорис Таузендфройнд, доктор истории, сотрудница Центра цифровых систем, Свободный университет Берлина, Иненшрассе, 24, 14195 г. Берлин, Германия, doris.tausendfreund@fu-berlin.de, https://orcid.org/0000-0003-2211-399X

Наталья Петровна Тимофеева, кандидат исторических наук, руководитель Научно-образовательного центра устной истории, Воронежский институт высоких технологий, ул. Ленина, 73a, 394043 г. Воронеж, Российская Федерация, timnp@mail.ru, https://orcid.org/0000-0002-5368-6144

Татьяна Васильевна Евдокимова, доктор исторических наук, профессор, заведующая кафедрой всеобщей истории и методики преподавания истории и обществоведения, Волгоградский государственный социально-педагогический университет, просп. им. В.И. Ленина, 27, 400066 г. Волгоград, Российская Федерация, eva_tan@mail.ru, https://orcid.org/0000-0003-0017-1363 